\title{
The benefit of co-trimoxazole treatment in the management of acute watery diarrhea caused by invasive bacterial infection
}

\author{
Bobby Setiadi Dharmawan, Agus Firmansyah, Imral Chair
}

\begin{abstract}
Background World Health Organization (WHO) states that antimicrobials are reliably helpful only for children with bloody diarrhea (probable shigellosis), suspected cholera with severe dehydration, and symptomatic infection caused by Giardia lamblia. The benefit of antimicrobial treatment in management of acute watery diarrhea caused by invasive bacterial infection is still debated. Objective To prove the benefit of co-trimoxazole treatment in the management of acute watery diarrhea caused by invasive bacterial infection in patients age 2-24 months.

Methods This was a randomized, double blind clinical trial involving infants and children aged 2-24 months with acute watery diarrhea caused by invasive bacterial infection without co-morbidity or complications. Invasive bacterial infection was defined by fecal leukocytes greater than ten cells $(+2)$ per high power field on stool. Subjects were assigned to receive either cotrimoxazole or placebo. The duration and frequency of diarrhea between two groups were compared.

Result Of 70 patients (co-trimoxazole, $n=35$; placebo, $n=35$ ), 42 (60\%) were children aged 12-24 months, of whom 61\% were undernourished. Males were affected 1.2 times as much as females. The clinical manifestations were mild-moderate dehydration (64\%), mucus in the stool (100\%), fever (24\%), vomiting (10\%), fever with vomiting (56\%) and lactose malabsorption (53\%). Duration of diarrhea in placebo group (mean 117.0 [SD 28.1] hours) was not significantly different $(\mathrm{P}=0.43)$ compared to that in co-trimoxazole group (mean 122.5 [SD 30.1] hours). Frequency of diarrhea per day in placebo group (mean 5.23 [SD 1.48] times) was not significantly different either $(\mathrm{P}=0.37)$ compared to that in co-trimoxazole group (mean 5.64 [SD 2.20] times).

Conclusion It is concluded that co-trimoxazole therapy provides no benefit to patients with acute watery diarrhea caused by invasive bacterial infection. This disorder seems to be selflimited.[Paediatr Indones 2007;47:104-108].
\end{abstract}

Keywords: invasive bacteria, diarrhea, fecal leukocyte, antimicrobial.

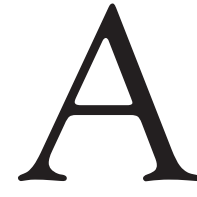

ntimicrobials, especially co-trimoxazole, are overused in the treatment of diarrhea in general population. Purnomo ${ }^{1}$ reported that $27.5 \%$ physicians in several primary health centers and private clinics in East Jakarta prescribed antimicrobials to all children under 5 years of age with acute diarrhea. ${ }^{1}$ Dwipurwantoro et al ${ }^{2}$ reported from 3 private hospitals in Jakarta, that of 67 in patients with acute diarrhea, $82 \%$ received antimicrobials. ${ }^{2}$ Although antimicrobials are reliably helpful for children with bloody diarrhea (probable shigellosis), suspected cholera with severe dehydration, and symptomatic infection caused by Giardia lamblia, the benefit of antimicrobial in management of acute watery diarrhea caused by invasive bacterial infection is still controversial. ${ }^{3-8}$ Heisig et al ${ }^{4}$ stated that inflammatory diarrhea is often bloody. However, in some cases of inflammatory diarrhea, the mucosa of the bowel appears grossly normal, while histologic review of biopsy specimens demonstrates signs of inflammation. Pai et $a l^{5}$ found that trimethoprimsulfamethoxazole (TMP-SMX) treatment in patients with Yersinia enterocolitica gastroenteritis didn't give

From The Department of Child Health, Medical School, University of Indonesia, Jakarta, Indonesia.

Reprint requests to: Bobby Setiadi Dharmawan, MD, Department of Child Health, Medical School, University of Indonesia, Jl. Salemba 6, Jakarta 10430, Indonesia. Tel 62-21-3907742, Fax 62-21-3907743. 
any benefit in shortening the clinical course. Proulx et $a^{6}$ also reported the same result in those with $E$. coli $\mathrm{O} 157: \mathrm{H} 7$ infection. On the other hand, DuPont et $a l^{7}$ found that the administration of TMP-SMX to patients with acute diarrhea caused by E. coli and Shigella infection shortened the duration of diarrhea. Thoren et $\mathrm{al}^{8}$ reported the same result in those with Enteropathogenic E. coli (EPEC) infection. GrisaruSoen et al $^{9}$ found that $80 \%$ of children with Salmonella spp bacteremia previously had a history of acute diarrhea. Therefore, in our department, patients with acute watery diarrhea caused by invasive bacterial infection confirmed by the finding of numerous fecal leukocytes were given co-trimoxazole treatment routinely.

While the benefit of antimicrobial in diarrhea treatment is still debated we presume that antimicrobial has benefits in the treatment of invasive bacterial diarrhea. The purpose of this study was to prove the benefit of co-trimoxazole administration in management of acute watery diarrhea caused by invasive bacterial infection in patients aged 2-24 months in Pediatric Department, Cipto Mangunkusumo Hospital, Jakarta.

\section{Methods}

A randomized, double blind, clinical trial was carried out on outpatients and inpatients infants and children with acute watery diarrhea caused by invasive bacterial infection treated at the Pediatric Department, Cipto Mangunkusumo Hospital. This study was performed from 25 August to 30 December 2005. Infants and children aged from 2 to 24 months with acute watery diarrhea caused by invasive bacterial infection were eligible for this study. Invasive bacterial infection was defined by finding of leukocytes greater than ten cells $(+2)$ per high power field on stool (preferably mucus) smear. Informed consent was obtained from parents. We excluded patients with diarrhea more than 72 hours, those who suffered from dysentery, cholera or had co-morbidity such as severe infection, immune deficiency or severe malnutrition, or a history of antimicrobial administration before admission and those who were sensitive to sulphonamide, were excluded from the study.

The total sample needed was 70 subjects. Sub- jects were randomly assigned to either receive cotrimoxazole or placebo. The duration and frequency of diarrhea per day were observed and recorded into a form by one of the authors and parents. The duration and frequency of diarrhea between two groups were compared and analyzed. The stools were also collected for bacterial culture with appropriate media (MacConkey agar and SS agar) and for antimicrobial sensitivity test at Pramita Laboratory Jakarta. Subjects that were considered suffered from adverse reactions such as dermatologic reactions (pruritis, skin rash) or prolonged diarrhea (more than 7 days) were considered as failure of therapy and received a specific treatment based on the etiology.

Student's t-test (2-tailed) and linear regression analysis with a level of significance $<0.05$ were performed using SPSS 12 for Windows program. The study was approved by the Committee for Medical Research Ethics of the Faculty of Medicine, University of Indonesia.

\section{Results}

Seventy patients were enrolled and divided into two groups (co-trimoxazole, $n=35$; placebo, $n=35$ ). The characteristics between two groups were similar (Table 1). Forty two subjects (60\%) were children aged 12 24 months, of whom $61.4 \%$ were undernourished. Males were affected 1.2 times as much as females.

Table 2 shows that the clinical manifestations were mucus in the stool (100\%), fever (24\%), vomiting $(10 \%)$, fever with vomiting $(56 \%)$, and without fever or vomiting (10\%).

Table 3 shows the comparison of duration and frequency of diarrhea per day between the two groups. Duration of diarrhea and frequency of diarrhea per day in placebo in co-trimoxazole group were not significantly difference. There was no failure of therapy reported during the study.

From the 70 stool specimens, EPEC was identified in $8.6 \%$ and Salmonella arizonae in $7.1 \%$ of the diarrheagenic pathogen but no Shigella spp. specimens were isolated. Twenty percent of the specimens were other nondiarrheagenic bacteria, such as Enterobacter sakazakii, Enterobacter cloacae, Serratia odorifera, Klebsiela pnemoniae, Acinetobacter calcoaceticus and Staphylococcus epidermidis. Non pathogenic E.coli was found 64.3\% from all speci- 
Bobby Setiadi Dharmawan et al: Effect of co-trimoxazole in acute watery diarrhea

Table 1. Characteristics of subjects in both treatment arms

\begin{tabular}{|c|c|c|c|c|}
\hline No & Characteristics & $\begin{array}{l}\text { Total } \\
\mathrm{n}(\%)\end{array}$ & $\begin{array}{c}\text { Placebo } \\
\mathrm{n}(\%)\end{array}$ & $\begin{array}{c}\text { Co-trimoxazole } \\
\mathrm{n}(\%)\end{array}$ \\
\hline \multirow[t]{3}{*}{1} & Age (months) & & & \\
\hline & $2-11$ & $28(40)$ & $14(40)$ & $14(40)$ \\
\hline & $12-24$ & $42(60)$ & $21(60)$ & $21(60)$ \\
\hline \multirow[t]{3}{*}{2} & Sex & & & \\
\hline & Boys & 38 (54) & $23(66)$ & $15(43)$ \\
\hline & Girls & $32(46)$ & $12(34)$ & $20(57)$ \\
\hline \multirow[t]{3}{*}{3} & Nutritional status & & & \\
\hline & Undernourished & $43(61)$ & 20 & $23(66)$ \\
\hline & Well-nourished & 27 (39) & $15(43)$ & $12(34)$ \\
\hline \multirow[t]{3}{*}{4} & $\begin{array}{l}\text { Duration of diarrhea } \\
\text { (hours) }\end{array}$ & & & \\
\hline & $0-48$ & $36(51)$ & 20 & $16(46)$ \\
\hline & $49-72$ & $34(49)$ & $15(43)$ & $19(54)$ \\
\hline \multirow[t]{3}{*}{5} & Degree of dehydrat & ion & & \\
\hline & No dehydration & $25(36)$ & $12(34)$ & $13(37)$ \\
\hline & Mild-moderate & $45(64)$ & $23(66)$ & $22(63)$ \\
\hline \multirow[t]{3}{*}{6} & Lactose malabsorp & tion & & \\
\hline & Yes & 37 (53) & $19(54)$ & $18(51)$ \\
\hline & No & $33(47)$ & $16(46)$ & $17(49)$ \\
\hline
\end{tabular}

Table 2. Clinical manifestations of the study subjects

\begin{tabular}{lcc}
\hline \multicolumn{1}{c}{ Clinical manifestations } & $\mathrm{n}$ & $\%$ \\
\hline Mucus in stool & 70 & 100 \\
Fever + vomiting & 39 & 56 \\
Fever & 17 & 24 \\
Vomiting & 7 & 10 \\
Without fever nor vomiting & 7 & 10 \\
\hline
\end{tabular}

mens. Considering all 11 diarrheagenic isolated, 6 EPEC and 3 Salmonella arizonae, were found to be resistant to co-trimoxazole. The distribution of the bacteria in diarrheal stool and the co-trimoxazole susceptibility test is shown in Table 4.

\section{Discussion}

There were several limitations of our study. Globally, the major cause of infectious diarrhea in infant and children is rotavirus. ${ }^{3,10,11}$ We did not search for rotavirus as the etiology of diarrhea, but we assumed that all stool specimens with more than ten leukocytes per high power field were considered invasive bacterial infection. ${ }^{12}$ Nevertheless, the rotavirus coinfection in bacteria caused diarrhea could occur. ${ }^{11}$ Because of laboratory investigation limitation we could not identify other invasive bacteriae such as Enteroinvasive E.coli and Campylobacter jejuni which are often found in the developing country as the diarrheagenic bacteria. ${ }^{3,11}$

Forty two subject $(60 \%)$ were children aged $12-$ 24 months (Table 1), this finding is similar to previous study. Diniz-santos et al $^{13}$ reported that the incidence of bacteria caused diarrhea increases in children more than 1 year of age, the period when children contact with environmental pathogen increases dramatically. Males were affected 1.2 times as much as females (Table 1) which is similar to results of previous studies. ${ }^{8.13,14}$ Until know, we have not been able to find any literature which explain the gender-specific difference in bacteria caused diarrhea. The most clinical manifestations in acute watery diarrhea caused by invasive bacteria were fever with vomiting $(55.7 \%)$ besides mucus

Table 3. Comparison of duration and frequency of diarrhea per day between two groups

\begin{tabular}{lccccc}
\hline Group & $\mathrm{n}(\%)$ & \multicolumn{2}{c}{$\begin{array}{c}\text { Duration of diarrhea } \\
\text { (hours) }\end{array}$} & \multicolumn{2}{c}{$\begin{array}{c}\text { Frequency per day } \\
\text { (times) }\end{array}$} \\
& & Mean \pm SD & $P$ & Mean \pm SD & $P$ \\
\hline Co-trimoxazole & $35(50)$ & $122.46 \pm 30.1$ & 0.43 & $5.64 \pm 2.20$ & 0.37 \\
Placebo & $35(50)$ & $116.97 \pm 28.11$ & & $5.23 \pm 1.48$ & \\
\hline
\end{tabular}

Table 4. The distribution of the bacteria in diarrheal stools and the co-trimoxazole susceptibility test

\begin{tabular}{lcccc}
\hline \multicolumn{1}{c}{ Bacteria } & Total $(\mathrm{n}=70)$ & \multicolumn{3}{c}{ Co-trimoxazole susceptibility } \\
& $\mathrm{n}(\%)$ & test \\
sensitive & intermediate & resistant \\
\hline EPEC & $6(8.6)$ & 0 & 0 & 6 \\
Salmonella arizonae & $5(7.1)$ & 1 & 1 & 3 \\
Enterobacter sakazakii & $3(4.3)$ & 1 & 0 & 2 \\
Enterobacter cloacae & $3(4.3)$ & 0 & 1 & 2 \\
Enterobacter aerogenes & $3(4.3)$ & 2 & 0 & 1 \\
Serratia odorifera & $2(2.9)$ & 0 & 0 & 2 \\
Klebsiela pneumoniae & $1(1.4)$ & 0 & 0 & 1 \\
Acinetobacter calcoaceticus & $1(1.4)$ & 0 & 0 & 1 \\
Staphylococcus epidermidis & $1(1.4)$ & 1 & 0 & 0 \\
Non pathogenic E.coli & $45(64.3)$ & - & - & - \\
\hline
\end{tabular}


in the stool (100\%) (Table 2). This finding is similar to Guandalini's report that fever with vomiting $(68 \%)$ is the most frequently found clinical manifestations in bacterial diarrhea, besides the mucus in stool. ${ }^{11}$

Robins-Browne et $a^{15}$ reported that duration of diarrhea in placebo group of Campylobacter jejuni gastroenteritis was 144 hours, while DuPont et al found that the duration of diarrhea in placebo group of uncomplicated Shigella gastroentritis was 109.6 hours. Our study has a similar results to previous studies, that clinical course in placebo group of uncomplicated acute watery diarrhea caused by invasive bacteria whereas no antimicrobial treatment was 116.97 hours (Table $3)$. The clinical course seems to be self-limited since no co-morbidity such severe infection, severe malnutrition, or immune deficiency. ${ }^{16,17}$ Our finding also supports the WHO statement that the antimicrobial treatment should not be given routinely except for children with bloody diarrhea (probable shigellosis) or suspected cholera with severe dehydration. 3,10

Duration of diarrhea in placebo group was not significantly different compared to those in cotrimoxazole group. Frequency of diarrhea per day in placebo group was also not significantly different compared to those in co-trimoxazole group (Table 3). Disadvantages of antimicrobial benefit in bacteria caused diarrhea management are also shown on previous studies. 5,6,14,15,18 Co-trimoxazole susceptibility test (Table 4) shows that most of diarrheagenic bacteria are resistant to this antimicrobial. The increase of this antimicrobial resistant and probable cotrimoxazole associated diarrhea may cause disadvantage to the clinical course in this study. ${ }^{19}$

Enteropathogenic E.coli was identified in $8.6 \%$ of all stool specimens which is similar to Diniz-Santos's study $(7.3 \%)$ of acute bacterial diarrhea in children in Brazil. ${ }^{13}$ Salmonella arizonae was isolated $7.1 \%$ of the diarrheagenic pathogen, and this finding is similar to those in developing country reported by WHO $(1-5 \%) .^{3}$ We have failed to isolate Shigella spp. This negative finding probably because patients with bloody diarrhea (probable shigellosis) which obviously need the antimicrobial treatment were excluded. The subjects age in our study ranged 2-24 months, meanwhile the highest incidence of shigellosis is usually occur in children between $4-10$ years of age. ${ }^{13}$ Finally, the laboratory investigation limitation may also cause this negative finding.
All of Enteropathogenic E. coli isolated (100\%) were found to be resistant to co-trimoxazole (Table 4), much higher than that of Pracoyo et al ${ }^{20}$ and Soelaeman et $a^{21}$. The overuse of co-trimoxazole in diarrhea management in general population probably causes the increase of antimicrobial resistance.

We conclude that co-trimoxazole provides no benefit to patients with acute watery invasive bacterial diarrhea. This clinical course seems to be self-limited since no co-morbidity or other complications occur. Administering antimicrobial in such patients should be discontinued.

\section{Acknowledgments}

The author wishes to thank all colleagues, Pramita laboratory, Abbott and also Otto pharmaceutical Industries Ltd. who have cooperated in this study.

\section{References}

1. Purnomo B. Perilaku dokter umum puskesmas dan dokter umum praktek swasta dalam tatalaksana diare balita di kotamadya Jakarta Timur [thesis]. Jakarta: Bagian Ilmu Kesehatan Anak FKUI; 1995.

2. Dwipoerwantoro PG, Hegar B, Witjaksono PA. Pola tata laksana diare akut di beberapa rumah sakit swasta di Jakarta; apakah sesuai dengan protocol WHO? Sari Pediatri 2004;6:182-7.

3. World Health Organization. The treatment of diarrhea: a manual for physicians and other senior health workers. WHO/CDD/SER/80.2 rev.4. Geneva, Switzerland: World Health Organization; 2005.

4. Heisig DG, Threatte GA, Henry JB. Laboratory diagnosis of gastrointestinal and pancreatic disorder. In: Henr JB, Davey FR, Herman CJ, McPherson, Pincus MR, Threatte GA, et al, editors. Clinical diagnosis and management by laboratory methods. 20th ed. Saunder;2001.p.462-75.

5. Pai C, Gillis F, Tuomanen E, Marks MI. Placebo-controlled double-blind evaluation of trimethoprim-sulfamethoxazole treatment of Yersinia enterocolitica gastroenteritis. J Pediatr 1984;104:308-11.

6. Proulx F, Turgeon JP, Delage G, Lafleur L, Chicoine L. Randomized, controlled trial of antibiotic therapy for Escherichia coli O157:H7 enteritis. J Pediatr 1992;121:299-303.

7. DuPont HL, Reves RR, Galindo E, Sullivan P, Wood LW, Mendiola JG. Treatment of traveler's diarrhea with 
Bobby Setiadi Dharmawan et al: Effect of co-trimoxazole in acute watery diarrhea

trimethoprim/sulfamethoxazole and with trimethoprime alone. N Engl J Med 1982;307:841-4.

8. Thoren A, Wolde-Mariam T, Stintzing G, Wadstrom, Habie D. Antibiotic in the treatment of gastroenteritis caused by enteropathogenic escherichia coli. J Infect Dis 1980;141:27-31.

9. Grisaru-Soen G, Wysoki MG, Keller N. Risk factors for development of nontyphoid salmonella bacterimia. Clin Pediatr 2004;43:825-9

10. Departemen Kesehatan RI. Epidemiologi dan etiologi diare. In: Ditjen PPM dan PIP Departemen Kesehatan, editor. Buku ajar diare. Jakarta: Depkes;1999.p.3-14.

11. Guandalini S. Acute diarrhea. In: Walker WA, Goulet O, Kleinman RE, Sherman PM, Shneider BL, Sanderson IR, editor. Pediatric gastrointestinal disease. $4^{\text {th }}$ ed. BC Decker;2004. p.16679.

12. DeWitt TG, Humphrey KF, McCarthy P. Clinical predictors of acute Bacterial Diarrhea in young children. Pediatrics 1985;76:551-6.

13. Diniz-Santos D, Santana JS, Barreto JR, Andrade MG, Silva LR. Epidemiological and microbiological aspects of acute bacterial diarrhea in children from Salvador, Bahia, Brazil. Braz J Infect Dis 2005;9:77-83.

14. Anders BJ, Paisley JW, Lauer BA, Reller LB. Double-blind placebo controlled trial of erythromycin for treatment of Campylobacter enteritis. Lancet 1982;1:131-2.

15. Robins-Browne RM, Mackenjee MK, Bodasing MN, Coovadia HM. Treatment of Campylobacter-associated enteritis with erythromycin. Am J Dis Child 1983; 137:282-5.

16. Checkley W, Gilman RH, Black RE, Lescano AG, Cabrera L, Taylor DN. Effect of nutritional status on diarrhea in Peruvian children. J Pediatr 2002;140:210-8.

17. Tomkins A. Nutritional status and severity of diarrhea among pre-school children in rural Nigeria. Lancet 1981;18:860-2.

18. Nelson JD, Kusmiesz H, Jackson LH, Woodman E. Treatment of Salmonella gastroenteritis with ampicillin, amoxicillin, or placebo. Pediatrics 1980;65:1125-30.

19. Jawetz E. Sulfonamides and trimethoprim. In: Katzung BG, editor.Basic and clinical pharmacology. 5th ed. Appleton and Lange, Connecticut; 1992.p.661-6.

20. Pracoyo NE, Sugianingsih S, Syamsidar, Misnardiarly. Resistensi antibotik terhadap kuman enteropatogen pada pasien diare dari beberapa rumah sakit di Jakarta. MKI 2001;28:705-8.

21. Soelaeman EJ, Purnomo B, Soehardjo HN, Digdowirogo HS. Causative agents of acute diarrhea in children. AsianOceanian J of Pediatric Child Health 2003;2:64-8. 